\title{
THE BRAZILIAN SOCIETY OF TOXINOLOGY (SBTX) COMES OF AGE
}

Toxinology as a Science in Brazil undoubtedly started with Vital Brazil Mineiro da Campanha (1865-1950), whose name carries with it the country, the state and the city of his birth. This physician became known, at first, by his clinical activities in Public Health dedicated to important diseases such as the yellow fever, bubonic pest, smallpox and the cholera, among others. However, impressed by the high number and seriousness of human accidents by venomous snake bites while living in Botucatu (1895-1897), a city in the state of São Paulo, he decided to change his study focus. Moving to the Bacteriological Institute [Instituto Bacteriológico], São Paulo State, in 1897, he performed his first experiments with snake venoms with the support of Drs. Adolfo Lutz and Albert Calmette, who shared with him their experience with anti-snake venom serum production.

The enthusiasm and dedication of Dr. Vital Brazil rendered him an invitation to move to the Serum Therapeutic Institute [Instituto Serumtherapico], São Paulo State. In 1901, Dr. Vital Brazil started his activities on the production of immune sera and vaccines in a laboratory that had been installed in a farm named Butantan. This was the first laboratory in Brazil dedicated to vaccine and antivenom production based on horse immunization. Today, Butantan Institute [Instituto Butantan], named after this pioneer farm, is an internationally known institution. Together with other governmental institutes, such as Ezequiel Dias Foundation [Fundação Ezequiel Dias] (Minas Gerais State) and Vital Brazil Institute [Instituto Vital Brazil] (created by Dr. Vital Brazil himself in July 1919, at Niteroi city, Rio de Janeiro State), Butantan Institute not only accounts for the production of antivenoms and other biotechnological products, but is also internationally known as a reference center in the study of animal venoms.

Besides Dr. Vital Brazil, other distinguished scientists wrote the first chapters in the history of Toxinology in Brazil; among them, Dr. Maurício Rocha e Silva and his collaborators who discovered the nonapeptide Bradykinin while studying snake venoms. Rocha e Silva also formed some authorities in animal venoms, such as Dr. Carlos Ribeiro Diniz (my dearest professor that introduced me to venom research at the Federal University of Minas Gerais [Universidade Federal de Minas Gerais]). Dr. Diniz (1919-2002) was an expert in snake and arthropod venoms. After leaving the university, he started and headed a research group on animal venoms at Ezequiel Dias Foundation, to which he dedicated the last 18 years of his life.

Dr. Sérgio H. Ferreira, one of Dr. Rocha e Silva's disciples, is well known for his studies on jararaca venom which led to the development of a therapeutic drug against hypertension (Captopril, used today worldwide). Of course, there are many other notable scientists that made relevant contributions in this area and that were not cited for reasons of space. This brief description, however, intends only to illustrate the importance and reach of the Toxinology field in our country.

The Brazilian Society of Toxinology (SBTx) was created on March $3^{\text {rd }}, 1988$, during the XII Annual Symposium of the Academy of Sciences of the state of São Paulo, and its subject at that time was "Proteins that are toxins". The foundation of SBTx was signed by about one hundred scientists, some of them already deceased (e.g. Drs. Carlos R. Diniz, Wilson T. Beraldo, Lineu Freire-Maia, Eva Kelen, Olga B. 
Henriques, Sebastião B. Henriques, H. Moussatche, W. Becak, A. M. Rothschild, José Moura Gonçalves, and Gastão Rosenfeld).

Prof. Oswaldo Vital Brazil (University of Campinas, São Paulo), son of Dr. Vital Brazil Mineiro da Campanha, followed the steps of his father in the study of snake venoms pharmacology and was the first president of SBTx. Next, the following toxinologists were in charge as Presidents: Julia Prado-Franceschi (University of Campinas, São Paulo), Eva Maria A. Kelen (Butantan Institute, São Paulo), Antonio Carlos Martins de Camargo (Butantan Institute, São Paulo), Mário Sérgio Palma (São Paulo State University), Gilberto Barbosa Domont (Federal University of Rio de Janeiro), and Krishnamurti de Moraes Carvalho (Federal University of Ceará, Fortaleza, Ceará).

Presently, SBTx counts with two hundred and twenty members. This number does not reflect all toxinologists in Brazil but represents a significant percentage of the Brazilian scientific production in Toxinology. We take this opportunity to invite the toxinologists, not associated yet, to join us in SBTx. We also encourage every Brazilian toxinologist to become a member of the International Society of Toxinology (IST), since a significant number of Brazilian toxinologists usually attend to its international meetings and our contribution to IST official journal (Toxicon) is relevant (about $30 \%$ of the papers in recent years).

In 2009, the biannual congress of SBTx will be held together with the triennial world congress of the IST (XVI IST World Congress and X SBTX Congress). The meeting is planned to be held from $15^{\text {th }}$ to $20^{\text {th }}$ of March in a very pleasant site near Recife (Pernambuco) at northeastern Brazil. It will congregate all the subareas of Toxinology (animal, plant and microbial toxins) including structural, proteomics, genomics, clinical and pharmacological approaches. We are very proud to be responsible for its organization and we invite all of you to collaborate with suggestions and to plan, from now on, to attend our meeting. It is being prepared with great care and we expect to receive about 500 subscriptions from Brazilian and foreign colleagues from all over the world who are interested in the advance of Toxinology. We hope we will be able to count on the participation of the most prominent scientists in the field as well as a great number of students, all of which will be heartily welcome.

Hope to see you there!

\section{CORRESPONDENCE TO:}

MARIA ELENA DE LIMA - President of the Brazilian Society of Toxinology, Universidade Federal de Minas Gerais, Instituto de Ciências Biológicas, Depto. de Bioquímica e Imunologia, Av. Antonio Carlos, 6627, 31.270-901, Belo Horizonte-MG, Brazil. Email: sbtxdir@gmail.com Home: http://www.sbtx.org.br 